\title{
The Roles of Spiritual Intelligence and Social Comparison Over Career Anxiety of Final Year Students
}

\author{
$1^{\text {st }}$ Yusuf Hamdani \\ Faculty of Social Science and Humanities, \\ UIN Sunan Kalijaga \\ Yogyakarta, Indonesia \\ hamdan.yuz@gmail.com
}

\author{
$2^{\text {nd }}$ Lisnawati* \\ Faculty of Social Science and Humanities, \\ UIN Sunan Kalijaga \\ Yogyakarta, Indonesia \\ lisna_wt@ymail.com
}

\author{
$3^{\text {rd }}$ Fitriana Widyastuti \\ Faculty of Social Science and Humanities, \\ UIN Sunan Kalijaga \\ Yogyakarta, Indonesia \\ fitrianawidyastuti01@gmail.com
}

\begin{abstract}
One of students experiences in adjustment problems is vocational adjustment. Failure in this adjustment causes career anxiety experience. This research focused on examining the role of spiritual intelligence and social comparison to the career anxiety in final year students. Quantitative method was used to examine the role of spiritual intelligence and social comparison over the career anxiety with multiple linear regressions technique. Eighty undergraduate students responded to the Career Anxiety Scale, the Spiritual Intelligence Scale, and the Social Comparison Scale. The results showed there was not simultaneously correlation of spirituality intelligence and social comparison over career anxiety. The study revealed two main findings. First, spiritual intelligence was negatively related to level of career anxiety. Second, there is no correlation of social comparison with career anxiety among final year students. This study showed that internal factor such as spiritual intelligence had more a prominent role over career anxiety compared to external factors. The implication of these results for potential intervention and future research are discussed.
\end{abstract}

Keywords - career anxiety, spiritual intelligence, social comparison

\section{INTRODUCTION}

At each stage of human development, there is a career development task that must be completed. Teenagers who are aged 15- 24 are at the career exploration stage. At this stage, adolescents search for information about themselves and the surrounding environment. They can identify their interests and abilities, as well as their values in society that can help them decide their career choice and commit to their career path [8].

The stage of career exploration need an adjustment, meanwhile failure on this process impacted to psychological problems. One of students' experiences in adjustment problems is vocational adjustment, which is adjustment in the fields of education and career. Failure in this adjustment causes career anxiety experience. Career anxiety is a realistic anxiety, namely anxiety or fear of uncertainty future in achieving an expected job. Career anxiety experienced by students lead to negative implications [10].
Haber and Runyon revealed that career anxiety is anxious, nervous, or tense feelings experienced by individuals in the face of something uncertain [7]. The uncertainty is something that has not happened in vulnerable life. Furthermore, Haber and Runyon said that career anxiety characterized by: 1) Cognitive aspect, define as an unpleasant feeling that triggers anxiety and worry; 2) Motor aspect, an unpleasant feeling that arises in the form of behavior such as squeezing fingers, stretching, biting the lips, clipping nails, nervous, and confused; 3) Somatic aspect, an unpleasant feeling that arises in biological physical reactions such as dry mouth, breathing difficulty, palpitations, cold hands and feet, dizziness, sweating, increased of blood pressure, and difficulty digesting food; 4) Affective aspects, an unpleasant feelings that arise in the form of emotions, feelings of tension due to excessive emotional outbursts such as confronting terror and views on a bleak future career [7].

Prawirohusudo stated that career anxiety can hinder appearance, caused obstacles, and hinder the individual's willingness to excel [15]. In addition, high career anxiety can lead individual to social dysfunction, for example students with feelings of anxiety bring them into helplessness and lack of self-actualization. According to Duran and Barlow, factors that can influence anxiety include biological, psychological and social contributions [4]. Nevid, et al. revealed that career anxiety can be influenced by biological factors, social and environmental factors, behavioral factors, and emotional cognitive factors [14].

One of internal factor played role in career anxiety is the level of intelligence in facing a crisis [11]. Some intelligence that exists in individuals are intellectual intelligence, emotional intelligence, and spirituality intelligence. These three intelligences have an important role in individuals, but spirituality intelligence has the highest contribution [11].

Zohar and Marshal define spiritual intelligence as ability to deal with and solve life's problems [11]. Spiritual intelligence is basically the ability to deal with problems of meaning or value. The used of intelligence terminology to place our behavior and life in the context of value and meaning, ability to judge that one's actions or way of life are 
more meaningful than others. Spiritual intelligence can be used when facing a crisis situation that makes us experience loss of self-order and is able to face the choices and realities that exist and to achieve personal maturity.

According to Zohar and Marshal aspects that affected spiritual intelligence include: 1) ability to be flexible, 2) high level of awareness, 3) ability to deal with and utilize suffering, 4) ability to deal with and surpass pain 5) Quality of life inspired by vision and values, 6) Unwillingness to cause unnecessary losses, 7) holistical thinking 8) Tendency to ask why and how, 9) being an independent [11]. Then for external factors of career anxiety in the form of social and environmental can be influenced by social comparison. Study that was conducted by Indrayani found the factors that cause anxiety in facing careers are personal problems, problems with parents, demands for achievement, and competition between friends [8]. The factor of competition between friends can cause individuals to make social comparisons.

Social comparison is the effort and process of influencing each other and competing behavior in social interactions caused by the need for self-evaluation. Social comparison arise driven by internal process within individual.. Ruble et al. said that individual has a tendency to look at himself and compare it with others in his environment and in the mass media [18]. Individuals have a greater tendency to compare themselves with others when self-evaluated that lead to dissatisfaction feeling. The research conducted by Jones shows that teenagers most often did social comparisons from models or peers to assess height, manner of appearance, and also intelligence or achievement; this applies to both girls and boys [19]. According to Festinger, in the process of comparing, there are two important things that become aspects of social comparison: 1) Ability, where the change in ability leads to a higher state; 2) Opinion in which this opinion is relatively easier to change [6].

This study aims to determine the relationship between spirituality intelligence and social comparison with career anxiety of final year students. This research was expected to be beneficial and understanding the role of spirituality intelligence and social comparison over career anxiety in the final year students of Faculty " $X$ " UIN Sunan Kalijaga Yogyakarta in particular and all final year students in general, so the research results could be used to develop prevention or intervention program to decrease career anxiety.

\section{METHOD}

\section{A. Participants}

The study included a total of 80 participants from the Faculty "X". The characteristics of these participants were final year students. The reason for selecting these participants was based on a preeliminary study that conducted by researchers, which resulted that the students of the Faculty "X" had the highest level of career anxiety. The sampling technique used was quota sampling which means the researcher determines the number of samples to be used in the study.

\section{B. Measures}

Anxiety Career Scale. The scale was adapted from career anxiety scale developed by Fatmawati [5] based on four aspects proposed by Haber and Runyon [7] consisting of, cognitive aspects, motor aspects, and somatic aspects. This scale consists of 21 items. The scale was a Likert type scale consisting of 5 options, ranging from "very appropriate", "appropriate", "neutral", "not appropriate", and "very not appropriate". The reliability test was conducted on 75 final year students of UIN Sunan Kalijaga Yogyakarta obtaining Cronbach's Alpha value of $\alpha=0.921$.

Spiritual Intelligence Scale. To measure the variable of spirituality intelligence, researchers used a measure of spirituality intelligence compiled by Rante et al. [17] based on the 9 aspects put forward by Zohar and Marshal [11]. The nine aspects are; flexibility, high awareness, face and utilize suffering, face and transcend pain, unwillingness to cause harm, quality of life, holistic outlook, tendency to ask questions, independent field. With a total of 21 items. The scale used was a Likert type scale consisting of 4 options, ranging from "very appropriate", "appropriate", "not appropriate", and "very unsuitable". The value of the Cronbach's Alpha spirituality intelligence scale is $\alpha=$ 0.854 . This shows that the scale of spirituality intelligence used in this study is reliable.

Social Comparison Scale. The social comparison was measured by adapting the scale compiled by Monika [13] based on the Lowa-Natherland Comparisson Orientation Measure (INCOM). This scale was compiled by Gibsons and Bunk based on aspects revealed by Festinger [6], namely the aspect of opinion and the aspect of ability.

This scale was a Likert scale with 11 items 5 alternative answers, namely "strongly disagree", "disagree", "neutral", "agree", and "strongly agree". The reliability test was conducted on 75 final year students of UIN Sunan Kalijaga Yogyakarta, Cronbach's Alpha value of $\alpha=0.810$.

\section{Procedure}

Data collection was carried out for two weeks starting from August 21, 2019 to September 2, 2019 by spreading the scale of research through Google from and a questionnaire scale of 80 responses. The sample selection process was carried out using the quota sampling method because the researcher has determined the number of samples to be used in the study, which was a total of 80 subjects. Characteristics of the sample in this study were final year students of Faculty " $\mathrm{X}$ " who were finishing their thesis.

\section{Data Analysis}

A number of statistical tests were run to analyze the relationship among three main variables: career anxiety, social comparison, and spiritual intelligence. Researchers conducted data input and extraction from each scale. Data processing begins by using the Microsoft Excel 2013 program, then for further statistical analysis using the IBM SPSS Statistics 22.0 program. 


\section{RESULTS}

Based on career anxiety categorization results at eighty subjects, it was found that as many as nine subjects $(11,25 \%)$ had a very high level of career anxiety and a total of fourty one subjects $(51,25 \%)$ had a high level of career anxiety. Meanwhile, as many as thirty subjects $(37,5 \%)$ had a medium level of career anxiety and none of the subjects $(0 \%)$ were categorized into low and very low level of career anxiety.

The results of the subjects' spiritual intelligence categorization showed that, there was one subject $(1,25 \%)$ who had a high level of spiritual intelligence, seventeen subjects $(21,25 \%)$ had a medium level of spiritual intelligence, fourty five subjects $(56,25 \%)$ had a low level of spiritual intelligence, and seventeen subjects $(21,25 \%)$ had a very low level of spiritual intelligence category.

On the other hand, the results of the subjects' social comparison categorization showed that there was one subject $(1,25 \%)$ who had a very high level of social comparison and as many as two subjects (2,5\%) were included in a high level of social comparison category. The number of subjects who had a medium and low level of social comparison was thirty seven $(46,25 \%)$ each and as amny as three subjects $(3,75 \%)$ were categorized into a very low one.

Afterwards, the researchers performed a normality test to determine whether the research data were distributed normally. The normality test was conducted by using the residual score of the three research variables. The normality test resulted a $\mathrm{p}$-value of 0,200 which means that $\mathrm{p}>0,05$. From that result we can concluded that the data has met the assumption of normal distribution of career anxiety, spiritual intelligence, and social comparison.

Linearity test was done after the normality test. Based on the result of career anxiety and spiritual intelligence variables, it was found that the F linearity value was 17,51 $(\mathrm{p}<0,05)$ for the linearity index and the $\mathrm{F}$ deviation from linearity value was $1,33(p>0,05)$ for the deviation from linearity index. Thus, it can be concluded that there was a linear relationship between the spiritual intelligence as an independent variable and the career anxiety as dependent variable. Then, based on the linearity test for the level of career anxiety and social comparison, it was found that the F linearity value was $2,879(\mathrm{p}<0,05)$ for the linearity index and the $F$ deviation from linearity value was 0,099 ( $p>$ $0,05)$ for the deviation from linearity index. Therefore, as the conclusion, there was a linear relationship between the independent variable social comparison and the dependent variable career anxiety.

The result of the multiple linear regression analysis by using stepwise method presented that the variable which made an effective contribution was only the spiritual intelligence variable, whilst the social comparison variable became the excluded variable. The regression coefficient (R) was 0,411 and the determinant coefficient (R-Squared) was 0,169 . This means that $16,9 \%$ of the diversity of the data can be explained by the variable in the regression model, that was the spiritual intelligence variable, and the rest $83,1 \%$ can be explained by other variables. The $F$ value of $15,89(\mathrm{p}<0,05)$ means that the spiritual intelligence variable in the model affected the career anxiety with a $95 \%$ confidence interval. It showed that spiritual intelligence and social comparison were not good predictors for career anxiety. As the result, then, the major hypothesis of this research was rejected. The brief description of the multiple linear regression analysis can be seen in table 2 below:

Table 2. A Simultaneous Verification of the Regression Coefficient with Stepwise Method

\begin{tabular}{llllll} 
& R & R Squared & F & $\begin{array}{l}\text { Sig. F } \\
\text { Change }\end{array}$ & Description \\
\hline $\begin{array}{l}\text { Spiritual } \\
\text { intelligence }\end{array}$ & $0,411^{\text {a }}$ & 0,169 & 15,89 & 0,000 & Entered \\
\hline
\end{tabular}

a. Predictors: (constant). Spiritual Intelligence

The next analysis examined whether the independent variables have a partial role for the dependent variable. The result of the t-test of spiritual intelligence and social comparison over career anxiety variable is presented in the table 3 below:

Table 3. Partial Verification of the Regression Coefficient

\begin{tabular}{lllll} 
Variable & $\boldsymbol{B}$ & $\mathbf{T}$ & Sig. & Description \\
\hline Spiritual Intelligence & $-0,650$ & $-3,987$ & 0,00 & $\begin{array}{l}\text { There is a partial } \\
\text { relationship }\end{array}$ \\
Social Comparison & 0,156 & 1,466 & 0,147 & $\begin{array}{l}\text { There is no partial } \\
\text { relationship }\end{array}$
\end{tabular}

Table 3. showed that the probability significance value (sig) of Spiritual Intelligence was $(\mathrm{p}<0,05)$, hence spiritual intelligence had a role over career anxiety. It means that the first minor hypothesis of the research was accepted, that spiritual intelligence plays a role over career anxiety of Faculty X's students of UIN Sunan Kalijaga Yogyakarta.

On the other hand, the probability value of social comparison was $0,147(\mathrm{p}>0,05)$ which means that social comparison did not play a role over career anxiety. Thus, the second minor hypothesis proposed by the research was rejected, that social comparison does not play a role over career anxiety of Faculty X's students of UIN Sunan Kalijaga Yogyakarta.

\section{IV.DISCUSSION}

This research was conducted to address the roles of spiritual intelligence and social comparison over career anxiety of Faculty X's students of UIN Sunan Kalijaga Yogyakarta. The results of the categorizations revealed that $41(51,25 \%)$ subjects had a high level of career anxiety whilst $39(48,75 \%)$ subjects were included into a medium level of career anxiety category. Meanwhile, the number of subjects had a low level of career anxiety was $0(0 \%)$. It means that the subjects tended to experience career anxiety, so they possessed a risk to felt anxious in deciding what they will do after graduating.

Career anxiety can be caused by unfinished developmental task, specifically the adolescent developmental task. Adolescence is a transition period between childhood and adulthood comprised of striking 
changes, such as physical, cognitive, and psychosocial changes. On each stage of human development, there is a career developmental task that must be completed.

Teenagers whose age ranged from 15-24 are at the career exploration stage. During this stage, they will seek information about themselves and their surrounding environment, identify their interests and abilities, and their values and those in the society that can help them make career choices so they can commit to certain career choices [8]. University students in general are individuals who are entering adolescence. Students who cannot complete the development at this stage will be vulnerable to career anxiety.

As stated by Danim, one of the developmental tasks during adolescence and early adulthood is to choose and prepare for a career [3]. Feldman, Olds and Papalia mentioned that deciding to pursue a higher degree of education or join the workforce is the problem teenagers face after completing their university education [16]. Teenagers who decide to join the workforce will face a new status as job seekers or unemployed. Difficulties in getting a job can cause anxiety, so the teenagers choosing to join the workforce can experience career anxiety.

On the other hand, from the research result was known that 39 students $(48,75 \%)$ had a medium level of spiritual intelligence, 41 students $(51,25 \%)$ had a low level of spiritual intelligence, and none of the students had a high level of spiritual intelligence $(0 \%)$. This data showed that the subjects did not have a good spiritual intelligence yet. Spiritual intelligence can be used to face a crisis that makes them lose self-order, to face choices and realities, and to achieve emotional maturity.

Career anxiety can be influenced by two main factors that are internal and external factors, which one of the internal factors is cognitive. The cognitive factor of career anxiety can be affected by an individual's spiritual intelligence level. Spiritual intelligence basically means the ability to engage with problems of meaning or value, that are the intelligence to put behavior and life in the context of a richer meaning as well as the intelligence to assess that one's action or way of life can be more meaningful than others [21]. Students who have a high level of spiritual intelligence can decide their way and purpose of life, making them able to avoid career anxiety. In contrast, students who have a low level of spiritual intelligence will face hurdles in determining their way and purpose in life, making these students to be vulnerable to career anxiety.

The result of partial analysis between career anxiety and spiritual intelligence indicated a significant negative correlation. It means that the first minor hypothesis proposed by this research was accepted. This was revealed through the correlation coefficient of spiritual intelligence of $-0,650$ with a significance level (p) of $0,00(\mathrm{p}<0,05)$, which means that the higher the career anxiety the students experienced, the lower the spiritual intelligence they possessed.

The result supports and broadens the previous research conducted by Lesmana who analyzed the correlation between spiritual intelligence and pre-retirement anxiety
[9]. The study displayed a significant negative correlation between spiritual intelligence and pre-retirement anxiety. The current research described that spiritual intelligence does not only affect pre-retirement anxiety but also career anxiety.

Furthermore, based on the social comparison categorization, it was found that as many as two subjects $(2,5 \%)$ had a high level of social comparison tendency, fifty one subjects $(63,75 \%)$ had a medium level of social comparison tendency, and twenty seven subjects $(33,75 \%)$ had the tendency of a low level of social comparison. The findings showed that the Faculty X' students of UIN Sunan Kalijaga Yogyakarta had a high level of social comparison tendency.

Festinger [6] who was the pioneer of the theory of social comparison said that every individual has the drive to evaluate their opinions and abilities. Festinger further asserted that knowledge of the situation at hand and the assessment of abilities an individual has play an important role in determining the proper behavior to display [6]. Ergo, the appropriate evaluation of the opinions and abilities has a significant role in every situation an individual will face in the future. Wood [20] explained that an individual tends to compare themselves with others when they are in a situation making them feel ambiguous by their current position.

Masters stated that there are two types and directions an individual takes in making a social comparison, that are upward comparison and downward comparison [12]. Upward comparison refers to the social comparison an individual makes by choosing a comparison object who they believe to be better than they are. Meanwhile, downward comparison means the social comparison an individual makes by choosing a comparison object who they believe to be less proficient than they are. According to Festinger, individuals tend to choose a superior group as their comparison object [6]. It signals that an individual inclines to see someone considered to be more successful than themselves in making a social comparison.

The results of partial correlation analysis between career anxiety and social comparison showed that, there was no significant negative correlation between two variables. It means that the second minor hypothesis proposed was rejected. This was known through the correlation coefficient of the social comparison variable of 0,156 with a significance level (p) of 0,147 ( $p>0,05)$. In other words, the level of social comparison did not have a correlation and did not play a role over career anxiety.

The results of this research contradicted with the results of the study conducted by Indriyani [8] who stated that one of the factors of career anxiety is a social factor that is peer competition, besides fear of failure and workforce demand. The peer competition factor in this research was included into the social comparison category. Encouragement from social environment and parents also become a supporting factor for an individual to avoid career anxiety.

The absence of correlation between career anxiety and social comparison can be caused by several factors. The first one was the lack of subjects for the research 
questionnaire which might decrease the possibility to identify the social comparison behavior of the research subjects. Also, there were other possible external factors that might influence career anxiety, that were social expectation and parental support [22].

Based on those predictors, this research revealed that an internal factor had a more prominent role and an influence over career anxiety compared to external factors. However, when the two predictors were correlated simultaneously, they did not show a significant negative correlation between spiritual intelligence and social comparison over career anxiety. This means that, the major hypothesis proposed by the researcher was rejected, indicated by the $\mathrm{F}$ value of 15,89 with $(\mathrm{p}<0,05)$ only on spiritual intelligence. The result of regression analysis also exemplified that the $\mathrm{R}$ Squared (R2) value was 0,169 or $16,9 \%$. Thus, only the spiritual intelligence variable that gave an effective contribution over career anxiety that was $19,6 \%$, whilst $83,4 \%$ was the effective contribution of other factors or variables that were not examined by this research.

The above explanation shows that one of the predictors was indeed correlated, nevertheless when tested together the correlation of both predictors was weak. As the consequence, there is a possibility of other stronger factors to correlate with career anxiety, as mentioned by Nevid, Rathus, and Greene [14]. They asserted that the factors contribute to career anxiety are biological factor caused by genetic disorder, social expectation, parental support, and traumatic event. Additionally, there are internal factors of career anxiety that may influence the result such as selfregulation and self-concept [14].

Self regulation as another internal factor, as explained by Azhari and Mirza [2], has a significant negative correlation over career anxiety at students. This depicted that the higher self-regulation has the lower correlation with the sudents experience with career anxiety. The study conducted by Apriliana [1] also revealed that career anxiety has a significant negative correlation with academic selfconcept of the students. The higher academic self-concept has corelatiom with lower career anxiety at the student experience.

\section{CONCLUSION}

The study revealed two main findings. First, spiritual intelligence was negatively related to level of career anxiety. Second, there is no correlation of social comparison with career anxiety among final year students. This study showed that internal factor such as spiritual intelligence had more a prominent role over career anxiety compared to external factors. The implication of these results for potential intervention and future research are discussed.

\section{REFERENCES}

[1] Aprilliana, R. (2016). Hubungan Antara Kecemasan Terhadap
Karir Masa Depan Dan Konsep Diri Akademik Dengan Prokrastinasi Skripsi Pada Mahasiswa. Jurnal Psikologi Universitas Islam Sultan Agung, Semarang , 11(1), 24-35.

[2] Azhari, T.K. \& Mirza, M. (2016). Hubungan regulasi diri dengan kecemasan menghadapi dunias kerja pada mahasiswa tingkat akhir universitas syiah kuala. Mediapsi, 2 (2), 23-29.

[3] Djibran, W. H. (2018). Analisis Tugas Perkembangan Mahasiswa Fakultas Ilmu Pendidikan Universitas Negeri Gorontalo. Jurnal Bikotik, 2(1), 73-114.

[4] Duran, V. M., \& Barlow, D. H. (2006). Psikologi abnormal. Yogyakarta: PustakaPelajar

[5] Fatmawati. (2016). Pengaruh Dukungan Sosial Terhadap Kecemasan Karir Siswa Kelas XI Akutansi di SMK Negeri 1 Bantul. E-Journal Bimbingan dan Konseling, 5(11), 70-84.

[6] Festinger, L. (1954) A Theory of Social Comparison Process. Human Relation, 1-16.

[7] Haber \& Runyon, R.P. (1984). Psychology of Adjustment. Illinois: The Dorsey Press.

[8] Indriyani. (2016). Kecemasan Aspirasi Karier Pada Remaja Putri Kelas Xi Di Smkn 3 Kasihan Bantul, Yogyakarta. E-Journal Bimbingan dan Konseling, 6(5), 107-119.

[9] Lesmana, D. (2014). Kecerdasan Spiritual Dengan Kecemasan Menghadapi Masa Pensiun. Jurnal Ilmiah Psikologi Terapan, 2 (1), 766-775.

[10] Listanto, V. \& Demak, I.P.K. (2015). Kecemasan pada mahasiswa angkatan 2010 yang mengerjakan tugas akhir program studi pendidikan dokter FKIK Untad tahun 2010. Medika Tadulako, Jurnal Ilmiah Kedokteran, 2 (1), 40-49.

[11] Marshall, Zohar, D. (2007). SQ : Kecerdasan Spiritualitas. Bandung: Mizan Pustaka.

[12] Masters, J. C. (1971). Social Comparison by Young Children. National Association for the Education of Young Children (NAEYC), 1-21.

[13] Monika, A.M. (2018) Hubungan Antara Perbandingan Sosial dan Intensi Turnover pada Karyawan Berusia 20-30 Tahun. E-Journal USD, 3 (1), 34-50

[14] Nevid, S.F, Rathus, A.S., \& Greene, B. (2003) Psikologi Abnormal. Jakarta : Penerbit Erlangga.

[15] Nikmah S., \& Nur I. (2015). Kecemasan pada Pengangguran Terdidik Lulusan Universitas. Jurnal Indigenous, 13 (1), 39-50.

[16] Papalia, D. E., Old, S. W., Feldman, \& R. D. (2008). Human Development. (terjemahan A. K. Anwar). Jakarta: Prenada Media Group. Papalia, E. D. (2009)

[17] Rante L. E., Nurcahyo F.A., \& Tanojo K. L. (2013) Hubungan antara Kecerdasan Spiritualitas dengan Prokastinasi Pada Mahasiswa Tingkat Akhir. Jurnal Humanitas, 10 (2), 59-72.

[18] Santrock, J.W. (2007). Perkembangan Anak. Jilid 1 Edisi kesebelas. Jakarta : PT. Erlangga.

[19] Suarya, I. (2018). Hubungan antara Komparasi Sosial dan Harga Diri terhadap Citra Tubuh pada Remaja Perempuan. Jurnal Psikologi Udayana,5 (2), 265-277.

[20] Wood, J. V. (1989). Theory and Research Concerning Social Comparison of Personal Attributes. American Psychological Association, 148-231.

[21] Ahmad, F. \& Ratnaningsih, I.Z. (2016). Hubungan antara kecerdasan spiritual dengan kecemasan menghadapi pensiun pada keryawan di pt perkebunan nusantara vii unit usaha betung kabupaten banyuasin sumatera selatan. Jurnal Empati, 5 (3), 467471

[22] Hurlock, E. (1996). Psikologi perkembangan. Alih bahasa: dr. Med. Metasari T. \& Dra. Muslichah Z. Jakarta: Erlangga 